\title{
2016 Rio Olympics: an epidemiological study of the men's and women's Rugby-7s tournaments
}

\author{
Colin W Fuller, ${ }^{1,2}$ Aileen Taylor, ${ }^{1}$ Martin Raftery ${ }^{1}$
}

${ }^{1}$ World Rugby, Dublin, Ireland ${ }^{2}$ Colin Fuller Consultancy Ltd, Sutton Bonington, UK

\section{Correspondence to}

Dr Colin W Fuller, World Rugby, World Rugby House, Pembroke Street Lower, Dublin 2, Ireland; colin.fuller@f-marc.com

Accepted 2 January 2017 Published Online First 30 January 2017

\section{CrossMark}

To cite: Fuller CW, Taylor A, Raftery M. Br J Sports Med 2017:51:1272-1278.

\section{ABSTRACT}

Objective To determine the incidence, severity and nature of injuries sustained during the men's and women's 2014/2015 and 2015/2016 Sevens World Series (SWS) and 2016 Olympic Games Rugby Sevens tournaments.

Design A prospective cohort study.

Participants All players from the core teams competing in the men's and women's 2014/2015 and 2015/2016 SWS (men: 15 teams; women: 11 teams) and all players from the men's ( 12 teams) and women's (12 teams) 2016 Rio Olympics tournaments.

Results The gold, silver and bronze medal-winning women's teams contained bigger players (body mass and stature) than other teams but the men's medal winning teams came from across the size spectrum of men's teams competing at Rio 2016. The incidences of injury in the men's tournaments (2014/2015 SWS: 107.7 injuries/1000 player-match-hours (95\% Cl 90.9 to 127.4$) ; 2015 / 2016$ SWS: 109.7 (95\% CI 93.7 to 128.6); Rio 2016: 124.5 (95\% Cl 73.7 to 210.2$)$ ) were higher but not statistically significant than those in the equivalent women's tournaments (2014/2015 SWS: $88.5(95 \% \mathrm{Cl} 68.4$ to 114.5$), p=0.250 ; 2015 / 2016$ SWS: 109.4 (95\% Cl 84.2 to 142.2), $p=0.984$; Rio 2016: 71.1 (95\% CI 35.6 to 142.2$), p=0.208)$. There were no statistically significant differences between the incidences of injury at the men's and women's 2016 Rio Olympics and the equivalent 2014/2015 (men: $p=0.603$; women: $p=0.562$ ) and 2015/2016 (men: $p=0.652$; women: $p=0.254$ ) SWS.

Conclusions The incidence, severity and nature of the injuries sustained during the men's and women's Rio 2016 Rugby-7s tournaments fell within the normal range of values for international Rugby-7s tournaments.

\section{INTRODUCTION}

Rugby-7s is the seven-a-side (backs: four; forwards: three) format of Rugby with games played on a standard rugby pitch but taking place over two 7 min periods. ${ }^{1}$ Because of their shorter duration, Rugby-7s games normally take place within a multiteam (12 to 16), multigame (five or six games per team) tournament structure extending over 2 or 3 days. This compares with the traditional game of Rugby that involves teams of 15 players (backs: 7; forwards: 8) and games played over two 40-min periods with typical rest periods of 4 days to 7 days between games. ${ }^{1}$ The largest international Rugby-7s competitions are World Rugby's annual Sevens World Series (SWS), which incorporate 9 or 10 tournaments within the men's and 5 or 6 tournaments within the women's competitions, and the quadrennial Rugby World Cup Sevens. ${ }^{2}$ The decision by the IOC to include men's and women's 12-team Rugby-7s tournaments within the Olympic Games has added two further high-profile international competitions.

The sport of Rugby has a history of introducing evidence-based player welfare initiatives based on data collected within national and international injury surveillance studies. The first injury surveillance study at a major international competition was implemented by the South African Rugby Football Union at the 1995 Rugby World Cup in South Africa: ${ }^{3}$ a practice adopted by World Rugby. ${ }^{4-7}$ In $2002,{ }^{8}$ the English Rugby Football Union (RFU) established an injury audit programme entitled 'England Professional Rugby Injury Surveillance Project' with annual status reports published on the Union's website. ${ }^{9}$ In New Zealand, results from the 'Rugby Injury Prevention Programme'10 led to joint ventures by the New Zealand Rugby Union and the country's national Accident Compensation Corporation to develop the injury prevention programme 'Tackling Rugby Injuries' in 1995 and subsequently to the 'Rugby Smart' programme in 2001. ${ }^{11} 12$ Detailed epidemiological studies by the RFU and World Rugby ${ }^{13} 14$ that examined the incidence, nature and causes of concussions sustained in Rugby-15s and Rugby-7s resulted in the development and implementation of a head injury assessment protocol in 2012. ${ }^{15} 16$

The fast-paced, physical nature of Rugby-7s coupled with an extensive year-round programme of international tournaments places a heavy load on players. ${ }^{1718}$ The addition of the Olympic Games Rugby-7s competition at the end of the players' established annual schedule of international tournaments adds to the physiological and psychological load experienced by elite players. ${ }^{19}$ The aim of this study was to assess and compare the incidence, severity and nature of injuries sustained during three competition stages associated with the men's and women's 2016 Rio Olympic Games, namely: (1) $2014 / 2015$ SWS, which was the primary qualification route for the 2016 Rio Games; (2) the $2015 / 2016$ SWS, which took place prior to the 2016 Rio Games; and (3) the 2016 Rio Olympic tournaments.

\section{METHOD}

The structure and nature of the SWS has been described in detail previously. ${ }^{17}{ }^{18}$ For the 2016 Rio Olympics, 11 qualifying countries together with Brazil as the host country provided the 12 participating teams in both the men's and women's competitions. The main qualification routes for the men's and women's Olympic competitions were the 2014/2015 SWS (October 2014 to May 2015): 


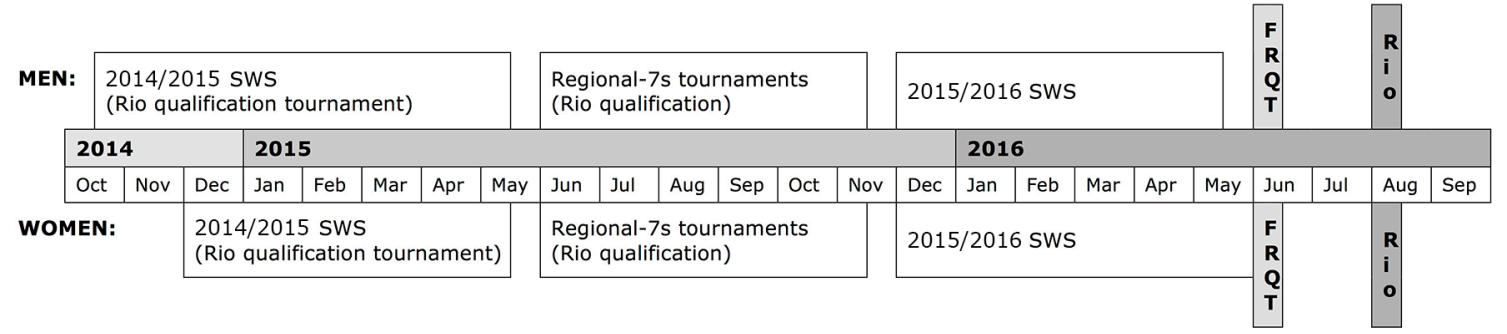

Figure 1 Timescale for men's and women's Rugby-7s tournaments leading up to the 2016 Rio Olympic Games. tournament. SWS: Sevens World Series; FRQT, Final Rio qualification tournament; Rio, Rio Olympic Games.

the four highest ranked teams at the end of these series being allocated places (men: Fiji, Great Britain, New Zealand, South Africa; women: Australia, Canada, Great Britain, New Zealand). One country (men: Argentina, Australia, France, Japan, Kenya, USA; women: Colombia, Fiji, France, Japan, Kenya, USA) qualifying from each of six continental tournaments (Africa, Asia, Europe, North America, Oceania and South America) that took place in 2015 together with the winners of repechage tournaments (men: Spain; women: Spain) that took place in Europe in June 2016 provided the remaining teams.

This study was a whole-population prospective, cohort study covering each tournament in the men's and women's 2014/2015 (men: 9 tournaments from 11 October 2014 to 17 May 2015; women: 6 tournaments from 1 December 2014 to 23 May 2015) and 2015/2016 (men: 10 tournaments from 4 December 2015 to 22 May 2016; women: 5 tournaments from 3 December 2015 to 29 May 2016) SWS and the 2016 Rio Olympic Games (men: 9 to 11 August 2016; women: 6 to 8 August 2016) (figure 1). Players' anthropometric (age, body mass, stature), match and training injuries and illnesses (body location, tissue type, Orchard code ${ }^{20}$ and nature, cause and time of onset) and match and training exposure data were collected for the 15 core men's teams and 11 core women's teams in each SWS and the 12 teams in the men's and women's Rio 2016 tournaments. Study manuals containing definitions and procedures together with copies of all audit documentation were sent to the medical teams supporting each country before the start of each competition. The definitions and procedures used in the study were compliant in all respects with the international consensus statement for

\begin{tabular}{|c|c|}
\hline Competition & Participating countries \\
\hline \multicolumn{2}{|c|}{$2014 / 2015$ SWS } \\
\hline Men & $\begin{array}{l}\text { Argentina, Australia, Canada, England, Fiji, France, Japan, } \\
\text { Kenya, New Zealand, Portugal, Samoa, Scotland, South } \\
\text { Africa, USA, Wales }\end{array}$ \\
\hline Women & $\begin{array}{l}\text { Australia, Canada, China, England, Fiji, France, New } \\
\text { Zealand, Russia, South Africa, Spain, USA }\end{array}$ \\
\hline \multicolumn{2}{|l|}{ 2015/2016 SWS } \\
\hline Men & $\begin{array}{l}\text { Argentina, Australia, Canada, England, Fiji, France, Kenya, } \\
\text { New Zealand, Portugal, Russia, Samoa, Scotland, South } \\
\text { Africa, USA, Wales }\end{array}$ \\
\hline Women & $\begin{array}{l}\text { Australia, Canada, England, Fiji, France, Ireland, Japan, } \\
\text { New Zealand, Russia, Spain, USA }\end{array}$ \\
\hline \multicolumn{2}{|c|}{2016 Rio Olympics } \\
\hline Men & $\begin{array}{l}\text { Argentina, Australia, Brazil, Fiji, France, Great Britain, } \\
\text { Japan, Kenya, New Zealand, South Africa, Spain, USA }\end{array}$ \\
\hline Women & $\begin{array}{l}\text { Australia, Brazil, Canada, Colombia, Fij, France, Great } \\
\text { Britain, Japan, Kenya, New Zealand, Spain, USA }\end{array}$ \\
\hline
\end{tabular}

SWS, Sevens World Series. epidemiological studies in Rugby. ${ }^{21}$ The definition of injury was 'Any injury sustained during the period of a Rugby-7s tournament (match or training session) that prevents a player from taking a full part in all training activities and/or match play for more than one day following the day of injury' and for illness was 'Any medical condition sustained while travelling to a tournament, while at a tournament or while travelling home at the end of a tournament that prevents a player from taking a full part in all training activities and/or match play for more than one day following the day of onset of the illness'.

Team match exposures were calculated on the basis of seven players/team exposed for $14 \mathrm{~min}$ per match $(20 \mathrm{~min}$ per match for tournament finals): no allowances were made for players temporarily (medical treatment, yellow card) or permanently (red card) removed from a match. Team doctors or physiotherapists recorded injury details and players were followed up post-tournament in order to obtain final confirmed diagnoses, surgical procedures and return-to-play/training dates. In those cases where injuries remained unresolved 3 months after the final match of a competition, team doctors/physiotherapists provided a return-to-play/training date for the injured player based on the injury diagnosis, the player's current state of recovery and the medical team's clinical judgement about the player's remaining rehabilitation time frame. Training exposures (mins) were recorded for players by each team at each tournament for the 5-day period prior to the start of each tournament using seven categories: warm-up, cool-down, rugby-skills (contact), rugby-skills (non-contact), conditioning (weights), conditioning (non-weights) and other.

Players' baseline data were summarised as means (SD), incidence of injury as injuries/1000 player-match hours (95\% CI), injury severity as the mean (days; $95 \% \mathrm{CI}$ ) and median (days; $95 \% \mathrm{CI}){ }^{22} \chi^{2}$ tests were used to assess differences in numbers of injuries; Z-tests for differences in incidences, mean severities and proportions of injuries; and the Mann-Whitney $U$ test for differences in the median severities of injuries. ${ }^{22}$ Trends in the incidence of injury across all tournaments were assessed using regression analyses. ${ }^{22}$ Due to the number of statistical comparisons made in this study, differences were considered to be statistically significant if $\mathrm{p} \leq 0.01$.

This study formed part of World Rugby's ongoing player welfare injury surveillance programme.

\section{RESULTS}

The countries included in each stage of the epidemiological study are listed in table 1 with the anthropometric data for the players involved presented in table 2 . For the men, the average age of players at Rio 2016 was significantly higher $(p<0.001)$ than that of players involved in both the 2014/2015 and 2015/2016 SWS but there were no statistically significant differences in the stature $(2014 / 2015, p=0.478 ; 2015 / 2016, p=0.153)$ or body mass 
Table 2 Players' anthropometric data as a function of competition and gender

\begin{tabular}{lrrr}
\hline & \multicolumn{3}{l}{ Mean $(\mathrm{SD}, \mathrm{n})$} \\
\cline { 2 - 4 } Gender/measure & \multicolumn{1}{l}{ 2014/2015 SWS } & 2015/2016 SWS & \multicolumn{1}{l}{2016 Rio } \\
\hline Men & & & \\
Age, years & $24.3(3.7,331)$ & $24.2(3.6,340)$ & $25.9(3.5,152)$ \\
Stature, cm & $183.1(7.0,331)$ & $183.6(7.0,340)$ & $182.6(7.5,152)$ \\
Body mass, kg & $91.2(8.4,331)$ & $92.0(9.2,340)$ & $90.5(9.4,152)$ \\
Women & & & \\
Age, years & $24.3(3.6,197)$ & $24.6(4.0,221)$ & $26.2(4.0,148)$ \\
Stature, cm & $169.0(5.6,197)$ & $168.4(5.8,221)$ & $167.3(5.9,148)$ \\
Body mass, kg & $67.4(6.1,197)$ & $67.8(6.0,221)$ & $66.4(6.7,148)$ \\
\hline
\end{tabular}

SWS, Sevens World Series.

$(2014 / 2015, p=0.418 ; 2015 / 2016, p=0.097)$ of the players. Similarly, the average age of the women's teams at Rio 2016 was significantly $(p<0.001)$ higher than that at the $2014 / 2015$ and 2015/2016 SWS. There were some differences in the stature $(2014 / 2015, p=0.006 ; 2015 / 2016, p=0.077)$ and body mass $(2014 / 2015, \mathrm{p}=0.150 ; 2015 / 2016, \mathrm{p}=0.036)$ of the female players at Rio 2016 but the differences were generally not statistically significant. While members of the gold, silver and bronze medal-winning women's teams were generally bigger, in terms of body mass and stature, than those of the other teams (figure 2), members of the men's medal winning teams came from across the size spectrum of teams competing at Rio 2016 (figure 3).

\section{Match injuries}

Table 3 summarises the number of match injuries, exposure and incidence of injury as a function of competition and gender. The incidences of injury in the men's tournaments were generally higher than those in the equivalent women's tournaments but the differences were not statistically significant (2014/2015 SWS: $p=0.250 ; 2015 / 2016$ SWS: $p=0.984$; Rio 2016: $p=0.208)$. There were no statistically significant differences between the incidences of injury recorded at the men's and women's 2016 Rio Olympic tournaments and the equivalent men's and women's 2014/2015 (men: $p=0.603$; women: $p=0.562$ ) and 2015/2016 (men: $\mathrm{p}=0.652$; women: $\mathrm{p}=0.254$ ) SWS.

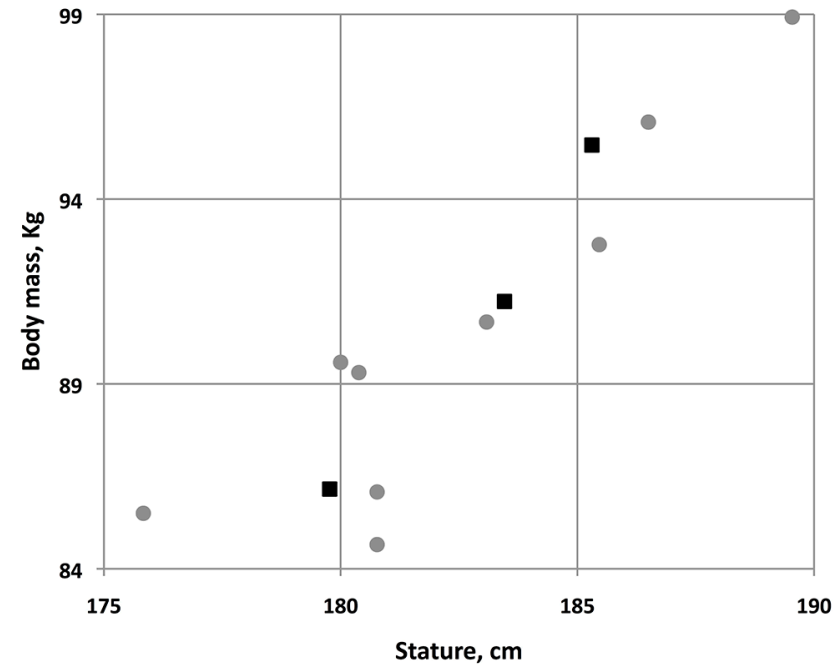

Figure 2 Comparisons of the mean body mass and stature of the men's Rio 2016 gold, silver and bronze medal-winning teams (squares) with other competing teams (circles).

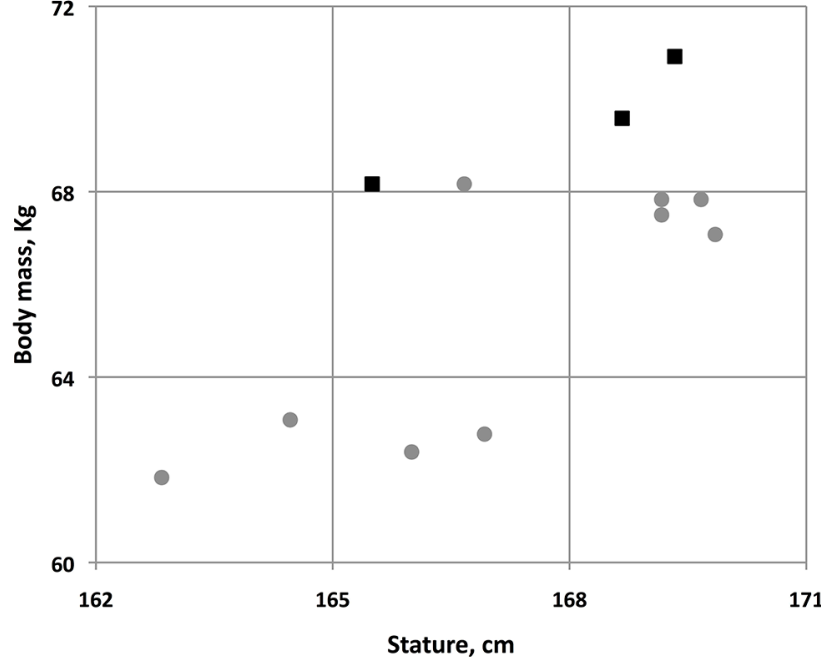

Figure 3 Comparisons of the mean body mass and stature of the women's Rio 2016 gold, silver and bronze medal-winning teams (squares) with other competing teams (circles).

More detailed assessments of the variations in the incidence of injury from tournament to tournament are shown for the men's and women's tournaments in figures 4 and 5, respectively. There were no significant trends in the incidences of injury across these tournaments for men $\left(R^{2}=0.001 ; p=0.902\right)$ or women $\left(\mathrm{R}^{2}=0.077 ; \mathrm{p}=0.409\right)$.

Table 4 summarises the mean and median severities of match injuries sustained during each competition as a function of gender. Although the severity of men's and women's injuries were higher during Rio 2016 than during the 2014/2015 and $2015 / 2016$ SWS, the differences were not statistically significant for the mean values (men-2014/2015 SWS: $p=0.069$, 2015/2016 SWS: $p=0.056$; women-2014/2015 SWS: $\mathrm{p}=0.379,2015 / 2016$ SWS: $\mathrm{p}=0.201$ ) and only for the men regarding the median value (men-2014/2015 SWS: $p=0.074$, 2015/2016 SWS: $p=0.004$; women-2014/2015 SWS: $\mathrm{p}=0.467,2015 / 2016$ SWS: $\mathrm{p}=0.227$ ).

Tables 5 and 6 present the locations and types of injuries sustained by players at each of the competitions.

Six on-pitch World Rugby Head Injury Assessment protocols were implemented for potential concussions during the men's and women's 2016 Rio tournaments but only one concussion in the men's and one in the women's competitions were confirmed. The most common injuries sustained by players during each competition are presented in table 7 .

Table 3 Numbers of match injuries (n), exposures (player matchhours) and incidences of injury (injuries/1000 player match-hours; $95 \% \mathrm{Cl}$ ) as a function of competition and gender

\begin{tabular}{llll}
\hline Gender/measure & 2014/2015 SWS & 2015/2016 SWS & 2016 Rio \\
\hline Men & & & \\
Match injuries & 135 & 153 & 14 \\
Exposure & 1253.9 & 1394.2 & 112.5 \\
Incidence & 107.7 & 109.7 & 124.5 \\
& $(90.9$ to 127.4$)$ & $(93.7$ to 128.6$)$ & (73.7 to 210.2) \\
Women & & & \\
Match injuries & 58 & 56 & 8 \\
Exposure & 655.2 & 511.7 & 112.5 \\
Incidence & $88.5(68.4$ to 114.5$)$ & 109.4 & 71.1 (35.6 to 142.2) \\
& & $(84.2$ to 142.2) & \\
\hline
\end{tabular}

SWS, Sevens World Series 


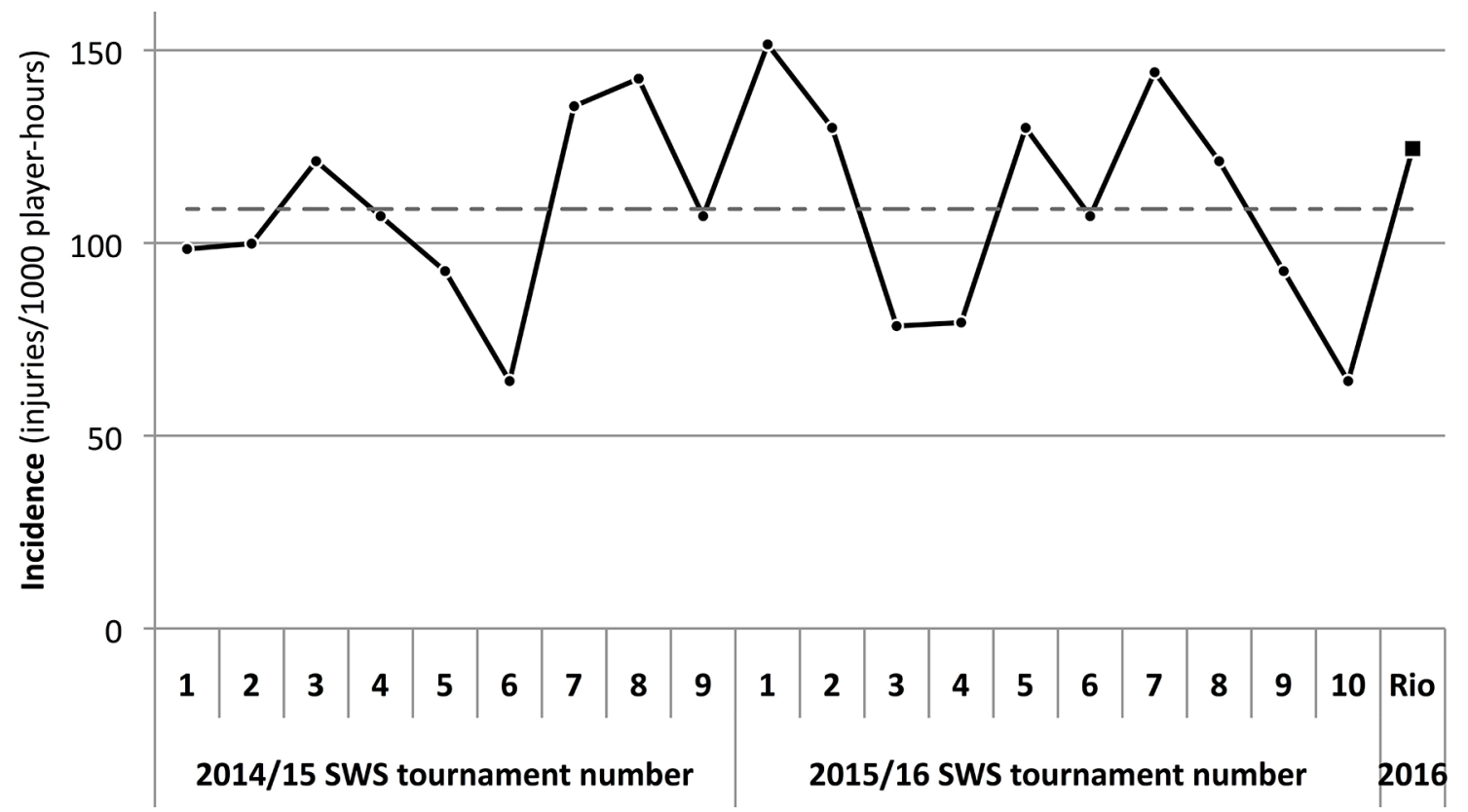

Figure 4 Variation in incidence of injury across men's 2014/2015 and 2015/2016 SWS tournaments (circles) and the Rio Olympics (squares); mean incidence across men's SWS tournaments (-----). SWS, Sevens World Series.

The injury burdens (total days lost to injury) associated with the injuries sustained at Rio 2016 were 1204 days for the men, of which $74 \%$ was accounted for by four injuries (ACL tears (2): 468 days; Achilles' tendon rupture: 234 days; posterior shoulder dislocation: 183 days) and 736 days for the women, of which $68 \%$ was accounted for by two ACL tears (500 days).

The nature and cause of onset of injuries sustained in each competition are shown as a function of gender in table 8 .

\section{Training exposures and injuries}

Mean team-training exposures undertaken during the competitions in the 5 days immediately prior to each tournament are shown in table 9 as a function of competition and gender.
For the men's teams, 11 training injuries were reported during the 9 2014/2015 SWS tournaments and 14 during the 10 2015/2016 SWS tournaments: these equate to incidences of 0.80 (95\% CI: 0.4 to 1.5 ) and 1.2 (95\% CI: 0.7 to 2.0 ) injuries/1000 player training-hours, respectively. The mean severity of these injuries was 31.5 days (median: 33) during the 2014/2015 SWS and 39.5 days (median: 27) during the 2015/2016 SWS. The men's teams reported no training injuries during Rio 2016. For the women, 6 training injuries were reported during the six 2014/2015 SWS tournaments and 10 during the five $2015 / 2016$ SWS tournaments, these equate to incidences of 0.95 (95\% CI: 0.4 to 2.1 ) and 2.2 (95\% CI: 1.2 to 4.1 ) injuries/1000 player training-hours, respectively. The

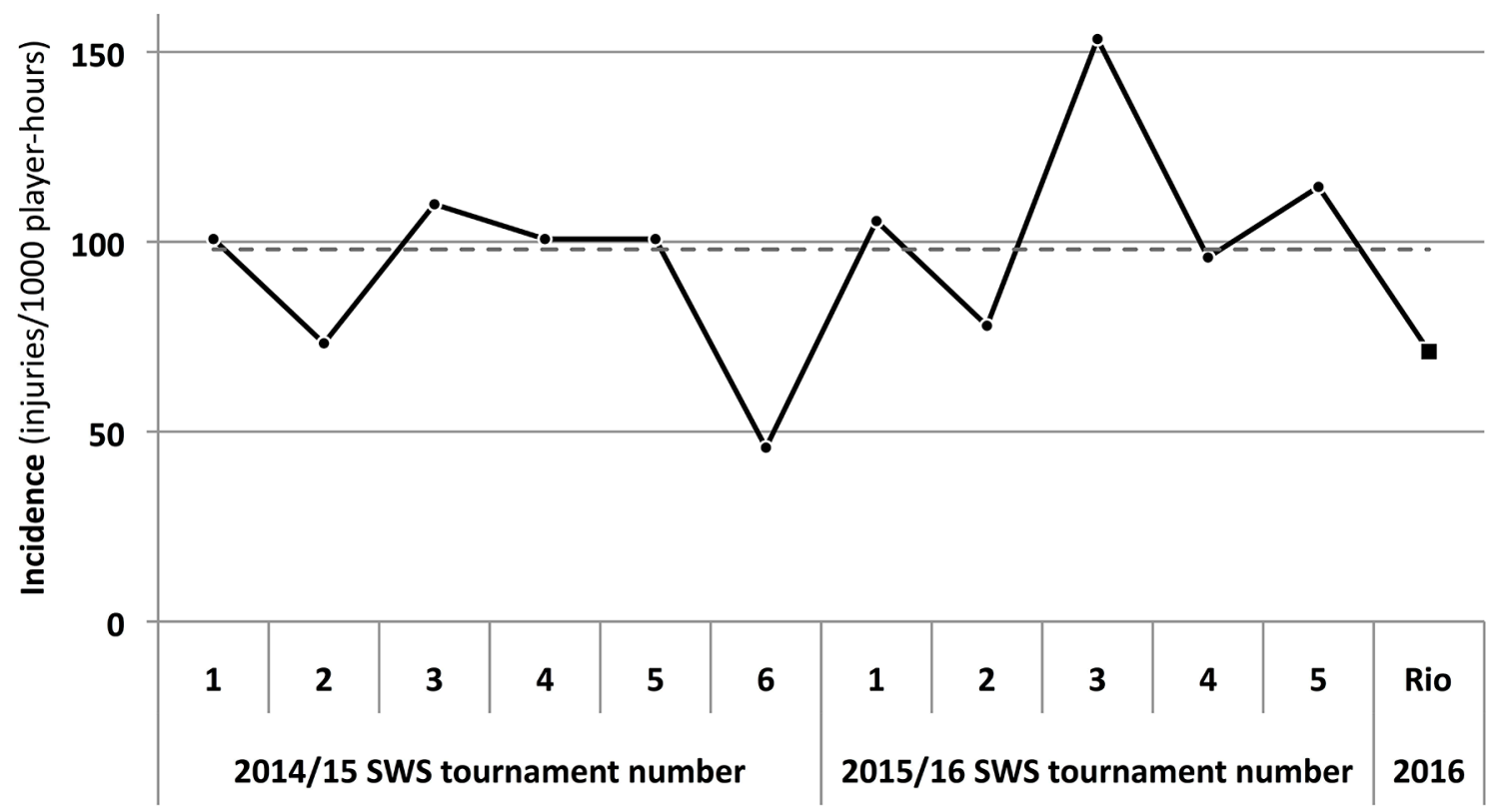

Figure 5 Variation in incidence of injury across women's 2014/2015 and 2015/2016 SWS tournaments (circles) and the Rio Olympics (squares); mean incidence across women's SWS tournaments (-----). SWS, Seven World Series. 
Table 4 Mean and median severities (days, 95\% Cl) of match injuries as a function of competition and gender

\begin{tabular}{|c|c|c|c|}
\hline \multirow[b]{2}{*}{ Gender/ severity } & \multicolumn{3}{|c|}{ Severity of injuries, days } \\
\hline & 2014/2015 SWS & 2015/2016 SWS & 2016 Rio \\
\hline \multicolumn{4}{|l|}{ Men } \\
\hline Mean & 41.3 (36.2 to 48.1$)$ & 39.0 (29.3 to 47.1$)$ & 86.0 (38.4 to 133.6$)$ \\
\hline Median & 28 (22 to 33$)$ & 21 (17 to 26$)$ & 40 (17 to 234$)$ \\
\hline \multicolumn{4}{|l|}{ Women } \\
\hline Mean & 59.7 (42.2 to 77.3 ) & 46.0 (33.2 to 58.8$)$ & $92.0(22.5$ to 161.5$)$ \\
\hline Median & 42 (26 to 50$)$ & 30 (22 to 38$)$ & 33 (21 to 250$)$ \\
\hline
\end{tabular}

SWS, Sevens World Series.

mean severity of these injuries was 27.0 days (median: 19) during the 2014/2015 SWS and 67.1 days (median: 9) during the 2015/2016 SWS. One minor hip flexor muscle strain was sustained during a rugby skills (contact) training session at Rio 2016 corresponding to 1.1 injury/1000 player training-hours.

\section{Illnesses}

For the men's teams, 11 illnesses were reported during the 2014/2015 SWS tournaments, of which 9 were infections (respiratory: 6 ; malaria: 1 ; chicken pox: 1 ; gastrointestinal: 1 ), 1 a non-specified virus and 1 an undiagnosed chest pain. Two of these illnesses occurred while travelling to, eight while at and one while travelling from a tournament. Sixteen cases of illness were reported during the 2015/2016 SWS tournament: of which 10 were related to gastrointestinal infections, 5 to a range of other infections and 1 to a pre-existing medical condition. Two of the illnesses occurred while travelling to, 13 while at and one while travelling from a tournament. These results represent an illness period prevalence of $3.3 \%$ and $4.7 \%$ for the $2014 / 2015$ SWS and 2015/2016 SWS, respectively. For the women's teams, two illnesses were reported during the 2014/2015 SWS (non-specific virus: 1 ; migraine: 1): 1 illness occurred while travelling to and one while at a tournament. Three illnesses were recorded during the 2015/2016 SWS (infection: 2; gynaecological: 1); all conditions arose while at a tournament. These results indicate an illness period prevalence of $1.0 \%$ and $0.4 \%$ for the $2014 / 2015$ SWS and 2015/2016 SWS, respectively. One male player and one female player experienced a respiratory condition during the Rio 2016 tournament; this corresponds to an illness period prevalence of $0.7 \%$ for both men and women.

\section{DISCUSSION}

Fourteen of the 152 male (prevalence: 9.2\%) and 9 of the 148 female (prevalence: 6.1\%) Rugby-7s players at the Rio 2016 Games sustained a match or training injury: this represents an overall prevalence of injury of $7.7 \%$. Compared with the 2014/2015 SWS and 2015/2016 SWS, the incidence of injuries at the 2016 Rio Games was higher for men but lower for women: these differences, however, were not statistically significant. The non-significant differences observed from tournament to tournament are due mainly to the small numbers of injuries and exposures recorded at individual tournaments: the men's and women's incidences of injury at Rio 2016 tournaments fell within these normal tournament-to-tournament variations. Rugby-7s is a full-contact team sport and therefore it is anticipated that players will experience a higher than average prevalence of injury, as most other Olympic sports are non-contact in nature. Despite this, a range of contact and non-contact Olympic sports, including athletics, BMX cycling,

Table 5 Locations of match injuries as a function of competition and gender

\begin{tabular}{|c|c|c|c|c|c|c|}
\hline \multirow[b]{3}{*}{ Location of injury } & \multicolumn{6}{|c|}{ Proportion of all injuries $(\%, 95 \% \mathrm{Cl})$} \\
\hline & \multicolumn{3}{|l|}{ Men } & \multicolumn{3}{|l|}{ Women } \\
\hline & 2014/2015 SWS & 2015/2016 SWS & 2016 Olympics & 2014/2015 SWS & 2015/2016 SWS & 2016 Olympics \\
\hline Head/neck & 21.5 (14.6 to 28.4$)$ & 20.3 (13.9 to 26.6$)$ & $14.3(0$ to 32.6$)$ & 19.0 (8.9 to 29.1$)$ & $23.2(12.2$ to 34.3$)$ & $12.5(0$ to 35.4$)$ \\
\hline Head/face & 19.3 (12.6 to 25.9$)$ & $19.0(12.7$ to 25.2$)$ & 7.1 (0 to 20.6$)$ & $17.2(7.5$ to 27.0$)$ & 21.4 (10.7 to 32.2$)$ & 12.5 (0 to 35.4 ) \\
\hline Neck/cervical spine & 2.2 (0 to 4.7 ) & $1.3(0$ to 3.1$)$ & 7.1 (0 to 20.6$)$ & $1.7(0$ to 5.1$)$ & $1.8(0$ to 5.3$)$ & $0.0(-)$ \\
\hline Upper limbs & 17.8 (11.3 to 24.2$)$ & $28.8(21.6$ to 35.9$)$ & 35.7 (10.6 to 60.8$)$ & $27.6(16.1$ to 39.1$)$ & $19.6(9.2$ to 30.0$)$ & $25.0(0$ to 55.0$)$ \\
\hline Shoulder/clavicle & $10.4(5.2$ to 15.5$)$ & 15.0 (9.4 to 20.7$)$ & 7.1 (0 to 20.6) & 10.3 (2.5 to 18.2$)$ & 7.1 (0.4 to 13.9$)$ & $0.0(-)$ \\
\hline Upper arm & 0.7 (0 to 2.2 ) & $0.7(0$ to 1.9$)$ & $0.0(-)$ & $0.0(-)$ & $0.0(-)$ & $0.0(-)$ \\
\hline Elbow & 0.7 (0 to 2.2$)$ & $1.3(0$ to 3.1$)$ & $0.0(-)$ & $1.7(0$ to 5.1$)$ & $3.6(0$ to 8.4$)$ & 12.5 (0 to 35.4$)$ \\
\hline Forearm & $0.0(-)$ & $2.6(0.1$ to 5.1$)$ & $0.0(-)$ & 1.7 (0 to 5.1$)$ & 3.6 (0 to 8.4$)$ & $0.0(-)$ \\
\hline Wrist & $1.5(0$ to 3.5$)$ & 1.3 (0 to 3.1$)$ & 7.1 (0 to 20.6) & 1.7 (0 to 5.1$)$ & $0.0(-)$ & $0.0(-)$ \\
\hline Hand/fingers & 4.4 (1.0 to 7.9$)$ & 7.8 (3.6 to 12.1$)$ & 21.4 (0 to 42.9$)$ & 12.1 (3.7 to 20.5$)$ & $5.4(0$ to 11.3$)$ & 12.5 (0 to 35.4$)$ \\
\hline Trunk & 4.4 (1.0 to 7.9$)$ & $3.9(0.8$ to 7.0$)$ & $0.0(-)$ & $5.2(0$ to 10.9$)$ & 8.9 (1.5 to 16.4$)$ & $0.0(-)$ \\
\hline $\begin{array}{l}\text { Sternum/ribs/upper } \\
\text { back }\end{array}$ & 3.0 (0.1 to 5.8$)$ & $2.6(0.1$ to 5.1$)$ & $0.0(-)$ & 1.7 (0 to 5.1$)$ & 5.4 (0 to 11.3$)$ & $0.0(-)$ \\
\hline Abdomen & 1.5 (0 to 3.5$)$ & 0.7 (0 to 1.9 ) & $0.0(-)$ & 1.7 (0 to 5.1$)$ & $1.8(0$ to 5.3$)$ & $0.0(-)$ \\
\hline Low back & $0.0(-)$ & $0.0(-)$ & $0.0(-)$ & $0.0(-)$ & $1.8(0$ to 5.3$)$ & $0.0(-)$ \\
\hline Sacrum/pelvis & $0.0(-)$ & 0.7 (0 to 1.9$)$ & $0.0(-)$ & $1.7(0$ to 5.1$)$ & $0.0(-)$ & $0.0(-)$ \\
\hline Lower limbs & 56.3 (47.9 to 64.7$)$ & 47.1 (39.1 to 55.0$)$ & 50.0 (23.8 to 76.2$)$ & 48.3 (35.4 to 61.1$)$ & 48.2 (35.1 to 61.3 ) & 62.5 (29.0 to 96.0$)$ \\
\hline Hip/groin & $3.0(0.1$ to 5.8$)$ & 1.3 (0 to 3.1$)$ & 7.1 (0 to 20.6) & $0.0(-)$ & $3.6(0$ to 8.4$)$ & $0.0(-)$ \\
\hline Thigh, posterior & 11.9 (6.4 to 17.3$)$ & 7.2 (3.1 to 11.3 ) & 7.1 (0 to 20.6) & 5.2 (0 to 10.9 ) & 7.1 (0.4 to 13.9$)$ & 12.5 (0 to 35.4$)$ \\
\hline Thigh, anterior & $4.4(1.0$ to 7.9$)$ & $2.6(0.1$ to 5.1$)$ & 7.1 (0 to 20.6) & $3.4(0$ to 8.1$)$ & $1.8(0$ to 5.3$)$ & $0.0(-)$ \\
\hline Knee & 12.6 (7.0 to 18.2$)$ & 9.8 (5.1 to 14.5$)$ & 14.3 (0 to 32.6$)$ & 25.9 (14.6 to 37.1$)$ & 16.1 (6.5 to 25.7$)$ & 25.0 (0 to 55.0$)$ \\
\hline Lower leg/Achilles & $5.2(1.4$ to 8.9$)$ & 7.2 (3.1 to 11.3 ) & 7.1 (0 to 20.6) & $5.2(0$ to 10.9$)$ & $5.4(0$ to 11.3$)$ & $0.0(-)$ \\
\hline Ankle & 15.6 (9.4 to 21.7$)$ & 17.0 (11.0 to 22.9$)$ & 7.1 (0 to 20.6) & 8.6 (1.4 to 15.8$)$ & 12.5 (3.8 to 21.2 ) & 25.0 (0 to 55.0$)$ \\
\hline Foot/toe & $3.7(0.5$ to 6.9$)$ & $2.0(0$ to 4.2$)$ & $0.0(-)$ & $0.0(-)$ & $1.8(0$ to 5.3$)$ & $0.0(-)$ \\
\hline
\end{tabular}

SWS, Sevens World Series. 
Table 6 Types of match injuries as a function of competition and gender

\begin{tabular}{|c|c|c|c|c|c|c|}
\hline \multirow[b]{3}{*}{ Type of injury } & \multicolumn{6}{|c|}{ Proportion of all injuries $(\%, 95 \% \mathrm{Cl})$} \\
\hline & \multicolumn{3}{|l|}{ Men } & \multicolumn{3}{|l|}{ Women } \\
\hline & 2014/2015 SWS & 2015/2016 SWS & 2016 Olympics & 2014/2015 SWS & 2015/2016 SWS & 2016 Olympics \\
\hline Bone & 8.1 (3.5 to 12.8$)$ & 9.2 (4.6 to 13.7$)$ & 14.3 (0 to 32.6$)$ & 15.5 (6.1 to 24.9$)$ & 8.9 (1.5 to 16.4$)$ & 12.5 (0 to 35.4$)$ \\
\hline Fracture & 7.4 (3.0 to 11.8$)$ & 8.5 (4.1 to 12.9$)$ & $14.3(0$ to 32.6$)$ & 13.8 (4.8 to 22.7 ) & 8.9 (1.5 to 16.4$)$ & 12.5 (0 to 35.4$)$ \\
\hline Other bone & 0.7 (0 to 2.2$)$ & $0.7(0$ to 1.9$)$ & $0.0(-)$ & $1.7(0$ to 5.1$)$ & $0.0(-)$ & $0.0(-)$ \\
\hline $\mathrm{C} / \mathrm{P}$ nervous system & $17.0(10.7$ to 23.4$)$ & 17.6 (11.6 to 23.7$)$ & $14.3(0$ to 32.6$)$ & 12.1 (3.6 to 20.5$)$ & 21.4 (10.7 to 32.2$)$ & 12.5 (0 to 35.4$)$ \\
\hline Concussion & 15.6 (9.4 to 21.7$)$ & $17.0(11.0$ to 22.9$)$ & 7.1 (0 to 20.6$)$ & $10.3(2.4$ to 18.3$)$ & 21.4 (10.7 to 32.2$)$ & 12.5 (0 to 35.4$)$ \\
\hline Nerve & $1.5(0$ to 3.5$)$ & $0.7(0$ to 1.9$)$ & 7.1 (0 to 20.6$)$ & $1.7(0$ to 5.1$)$ & $0.0(-)$ & $0.0(-)$ \\
\hline $\begin{array}{l}\text { Joint (non-bone)/ } \\
\text { ligament }\end{array}$ & 40.0 (31.7 to 48.3$)$ & $41.2(33.4$ to 49.0$)$ & 35.7 (10.6 to 60.8$)$ & 44.8 (31.9 to 57.7$)$ & $41.1(28.2$ to 54.0$)$ & $62.5(29.0$ to 96.0$)$ \\
\hline Dislocation/subluxation & $5.9(1.9$ to 9.9$)$ & 8.5 (4.1 to 12.9$)$ & 14.3 (0 to 32.6$)$ & $6.9(0.3$ to 13.5$)$ & $10.7(2.6$ to 18.8$)$ & $0.0(-)$ \\
\hline Lesion meniscus/disc & $4.4(1.0$ to 7.9$)$ & $2.0(0$ to 4.2$)$ & $0.0(-)$ & 3.4 (0 to 8.2 ) & $1.8(0$ to 5.3$)$ & $0.0(-)$ \\
\hline Ligament sprain & 29.6 (21.9 to 37.3 ) & 30.7 (23.4 to 38.0$)$ & $21.4(0$ to 42.9$)$ & 34.5 (22.1 to 46.8$)$ & 28.6 (16.7 to 40.4$)$ & 62.5 (29.0 to 96.0$)$ \\
\hline Muscle/tendon & 31.1 (23.3 to 38.9 ) & 25.5 (18.6 to 32.4$)$ & 35.7 (10.6 to 60.8$)$ & 24.1 (13.0 to 35.2 ) & 28.6 (16.7 to 40.4$)$ & $12.5(0$ to 35.4$)$ \\
\hline Haematoma/bruise & 9.6 (4.7 to 14.6$)$ & 9.2 (4.6 to 13.7$)$ & $14.3(0$ to 32.6$)$ & 12.1 (3.6 to 20.5 ) & 14.3 (5.1 to 23.5 ) & $0.0(-)$ \\
\hline Muscle rupture/cramp & 17.8 (11.3 to 24.2$)$ & 11.8 (6.7 to 16.9$)$ & $14.3(0$ to 32.6$)$ & $6.9(0.3$ to 13.5$)$ & 12.5 (3.8 to 21.2 ) & 12.5 (0 to 35.4$)$ \\
\hline Tendon injury & 3.7 (0.5 to 6.9$)$ & 4.6 (1.3 to 7.9$)$ & 7.1 (0 to 20.6) & $5.2(0$ to 10.9 & $1.8(0$ to 5.3$)$ & $0.0(-)$ \\
\hline Skin & $3.0(0.1$ to 5.8$)$ & $3.3(0.5$ to 6.1$)$ & $0.0(-)$ & 1.7 (0 to 5.1$)$ & $0.0(-)$ & $0.0(-)$ \\
\hline Laceration & $3.0(0.1$ to 5.8$)$ & $2.0(0$ to 4.2$)$ & $0.0(-)$ & $1.7(0$ to 5.1$)$ & $0.0(-)$ & $0.0(-)$ \\
\hline Other injuries & 0.7 (0 to 2.2 ) & $1.3(0$ to 3.1$)$ & $0.0(-)$ & $1.7(0$ to 5.1$)$ & $0.0(-)$ & $0.0(-)$ \\
\hline Dental & $0.0(-)$ & $3.3(0.5$ to 6.1$)$ & $0.0(-)$ & $0.0(-)$ & $0.0(-)$ & $0.0(-)$ \\
\hline Visceral & 0.7 (0 to 2.2 ) & $0.0(-)$ & $0.0(-)$ & $0.0(-)$ & $0.0(-)$ & $0.0(-)$ \\
\hline Other & $0.0(-)$ & $2.0(0$ to 4.2$)$ & $0.0(-)$ & $1.7(0$ to 5.1$)$ & $0.0(-)$ & $0.0(-)$ \\
\hline
\end{tabular}

$\mathrm{C} / \mathrm{P}$, central and peripheral; SWS, Sevens World Series.

boxing, football, handball, taekwondo, triathlon and weightlifting, have reported similar or higher prevalence of time-loss injuries. $^{2324}$ The prevalence of concussion among the Rugby-7s players at Rio $2016(0.7 \%)$ was less than that reported during the preceding 2015/2016 SWS: this prevalence was also less than that reported at previous Olympic Games for bicycle motor cross (BMX) cycling $(2.1 \%)^{24}$ and similar to that reported for baseball, boxing, football and taekwondo. ${ }^{23} 24$ The mean severity of injuries sustained by both men's and women's Rugby-7s teams were higher at the Rio 2016 tournaments compared with the 2014/2015 and 2015/2016 SWS: this resulted mainly from two ACL injuries being sustained in both the men's and the women's competitions, each of which required surgery. Rugby-7s players experienced a much lower prevalence of illness at 2016 Rio $(0.7 \%)$ compared with the average prevalence of illnesses reported for athletes at the 2012 Olympic Games (7\%). ${ }^{24}$

Table 7 The most common match injuries as a function of competition and gender

\begin{tabular}{clll}
\hline \multirow{4}{*}{ Gender, ranking } & \multicolumn{3}{l}{ Most common injuries, $(\mathrm{n}, \%)$} \\
\cline { 2 - 4 } Men & 2014/2015 SWS & 2015/2016 SWS & 2016 Rio \\
\hline 1 & Concussion & Concussion & Knee ligament \\
& $(21,15.6)$ & $(26,17.0)$ & $(2,14.3)$ \\
\hline 2 & Ankle ligament & Ankle ligament & Hand/finger fracture \\
& $(20,14.8)$ & $(23,15.0)$ & $(2,14.3)$ \\
Women & & & \\
1 & Knee ligament & Concussion & Ankle ligament \\
& $(13,22.4)$ & $(12,21.4)$ & $(2,25.0)$ \\
\hline 2 & Concussion & Knee ligament & Knee ligament \\
& $(6,10.3)$ & $(5,8.9)$ & $(2,25.0)$ \\
& & Ankle ligament & \\
& & $(5,8.9)$ & \\
\hline
\end{tabular}

World Rugby has an established player welfare research programme, which investigates aspects of the game that may impact on players' risk of injury and/or ill health; ${ }^{25}$ particular attention is given to the investigation of modifiable risk factors. One aspect of the present study was, therefore, to review whether the timing and/or format of the Rio Olympic tournament impacted on player welfare. The team qualification process for the Rio 2016 Olympics extended from October 2014 through to June 2016 with the final qualifying country for both the men's and women's competitions not being confirmed until 6 weeks before the start of the Games. This process had the potential for some countries to take part in 9 qualifying

Table 8 Nature and cause of match injuries as a function of competition and gender

\begin{tabular}{|c|c|c|c|}
\hline \multirow{2}{*}{$\begin{array}{l}\text { Nature/cause of } \\
\text { injury onset }\end{array}$} & \multicolumn{3}{|c|}{ Proportion of all injuries $(\%, 95 \% \mathrm{Cl})$} \\
\hline & 2014/2015 SWS & 2015/2016 SWS & 2016 Rio \\
\hline \multicolumn{4}{|l|}{ Nature } \\
\hline \multicolumn{4}{|l|}{ Men } \\
\hline Acute & 95.6 (92.1 to 99.0$)$ & 94.8 (91.2 to 98.3$)$ & 92.9 (79.4 to 100$)$ \\
\hline Gradual & 4.4 (1.0 to 7.9$)$ & 5.2 (1.7 to 8.8$)$ & 7.1 (0 to 20.6) \\
\hline \multicolumn{4}{|l|}{ Women } \\
\hline Acute & 93.1 (86.6 to 99.6$)$ & 92.9 (86.1 to 99.6$)$ & 87.5 (64.6 to 100$)$ \\
\hline Gradual & $6.9(0.4$ to 13.4$)$ & 7.1 (0.4 to 13.9$)$ & 12.5 (0 to 35.4$)$ \\
\hline \multicolumn{4}{|l|}{ Cause } \\
\hline \multicolumn{4}{|l|}{ Men } \\
\hline Contact & 77.7 (70.5 to 84.8) & 85.1 (79.4 to 90.9$)$ & 85.7 (67.4 to 100$)$ \\
\hline Non-contact & 22.3 (15.2 to 29.5$)$ & 14.9 (9.1 to 20.6$)$ & 14.3 (0 to 32.6 ) \\
\hline \multicolumn{4}{|l|}{ Women } \\
\hline Contact & 92.9 (86.1 to 99.6$)$ & 96.2 (90.9 to 100$)$ & 83.3 (53.5 to 100$)$ \\
\hline Non-contact & $7.1(0.4$ to 13.9$)$ & 3.8 (0 to 9.1$)$ & 16.7 (0 to 46.5 ) \\
\hline
\end{tabular}




\begin{tabular}{|c|c|c|c|}
\hline \multirow{2}{*}{$\begin{array}{l}\text { Gender/nature of } \\
\text { training exposure }\end{array}$} & \multicolumn{3}{|c|}{ Mean team-training hours per tournament } \\
\hline & $2014 / 2015$ SWS & 2015/2016 SWS & 2016 Rio \\
\hline \multicolumn{4}{|l|}{ Men } \\
\hline Warm-up & 13.4 & 13.4 & 14.0 \\
\hline Cool-down & 8.0 & 6.6 & 7.4 \\
\hline Rugby skills (contact) & 7.5 & 6.6 & 11.3 \\
\hline $\begin{array}{l}\text { Rugby skills (non- } \\
\text { contact) }\end{array}$ & 25.2 & 24.1 & 31.1 \\
\hline $\begin{array}{l}\text { Conditioning } \\
\text { (weights) }\end{array}$ & 13.2 & 14.7 & 18.9 \\
\hline $\begin{array}{l}\text { Conditioning (non- } \\
\text { weights) }\end{array}$ & 1.7 & 5.9 & 3.1 \\
\hline Other & 4.0 & 2.4 & 1.0 \\
\hline $\begin{array}{l}\text { Total team training } \\
\text { exposure }\end{array}$ & 73.0 & 73.7 & 86.8 \\
\hline \multicolumn{4}{|l|}{ Women } \\
\hline Warm-up & 18.1 & 14.9 & 10.7 \\
\hline Cool-down & 8.5 & 8.5 & 7.7 \\
\hline Rugby skills (contact) & 8.7 & 6.8 & 10.5 \\
\hline $\begin{array}{l}\text { Rugby skills (non- } \\
\text { contact) }\end{array}$ & 24.3 & 25.7 & 23.7 \\
\hline $\begin{array}{l}\text { Conditioning } \\
\text { (weights) }\end{array}$ & 6.4 & 9.9 & 10.1 \\
\hline $\begin{array}{l}\text { Conditioning (non- } \\
\text { weights) }\end{array}$ & 2.8 & 4.4 & 5.6 \\
\hline Other & 8.6 & 7.9 & 4.9 \\
\hline $\begin{array}{l}\text { Total team training } \\
\text { exposure }\end{array}$ & 77.4 & 78.1 & 73.2 \\
\hline
\end{tabular}

tournaments during the 2014/2015 SWS (October 2014 to May 2015), 3 qualifying tournaments during June and July 2015, 10 tournaments during the 2015/2016 SWS (December 2015 to May 2016), a final qualifying tournament in June 2016 followed by the Olympic tournament in August 2016. This meant that a qualifying country might need to take part in 24 individual tournaments over a 21-month period: this competitive load would also be amplified by the physiological and psychological loads associated with related travel across six continents and multiple time zones. ${ }^{19}$ It is worth noting that the gold, silver and bronze medal winning countries in both the men's and women's Rio 2016 tournaments came from the world's four top-ranked teams that qualified directly from the 2014/2015 SWS; these countries had the benefit of not being required to take part in any of the additional qualifying tournaments and could therefore rest and prepare specifically for the Olympic Games in the periods from May to December 2015 and May to August 2016.

There has been increasing discussion about the effect of changes in pre-competition training loads and their potential to impact on players' risk of injury. ${ }^{19} 2627$ It has been reported that increases in an athlete's short-term training load compared with their baseline training load can increase fatigue and enhance the risk of injury. ${ }^{19} 27$ The pre-Rio training load for women's teams were comparable to those experienced prior to tournaments in the 2014/2015 and 2015/2016 SWS and there was no increase in the women's injury risk. On the other hand, the pre-Rio training load experienced by men's teams was almost $20 \%$ higher than that undertaken prior to tournaments in the $2014 / 2015$ and 2015/2016 SWS tournaments and there was a higher than average risk of injury. Whether the higher incidence of injury observed for men at Rio 2016 was the result of
What are the findings?

- This is the first study to evaluate the incidence of injury and illness in men's and women's Rugby-7s at the Olympics.

- The incidence, severity and nature of injuries sustained during the Games were similar to those reported for the Sevens World Series.

- The prevalence of illnesses among male and female Rugby-7s players was low during the Rio Games.

\section{How might it impact on clinical practice in the future?}

- The results enable the level of team and tournament medical support required for an Olympics Rugby-7s tournament to be evidence-based.

- The high incidence and severity of injury confirms the need for teams to implement effective injury prevention strategies in Rugby-7s.

normal tournament-to-tournament variations in the incidence of injury or was a result of the change in precompetition training load cannot be determined from the information available, as the long-term training loads of the teams prior to the Rio 2016 Olympics were not available.

There are a number of strengths and a few limitations associated with the present study. The methodology employed was consistent across all men's and women's competitions and it followed the international consensus statement for epidemiological studies in Rugby. The specific nature of the injuries and illnesses was diagnosed and reported by qualified physicians and physiotherapists following detailed medical examinations of the injured players. An important aspect of this study is that all injuries and illnesses were followed up postevent and returnto-play dates were reported: this was particularly important for those injuries where a definitive diagnosis was not possible without the use of imaging and where injuries persisted for several weeks. While the 2014/2015 and 2015/2016 SWS studies each covered between 5 and 10 individual tournaments, Rio 2016 represented just one single tournament and, therefore, the exposure and number of injuries recorded were too small to provide definitive assessments or more wide-ranging conclusions.

In conclusion, the incidence, severity and nature of the injuries sustained during the men's and women's Rio 2016 Rugby-7s tournaments fell within the normal range of values experienced at international Rugby-7s tournaments.

Acknowledgements The authors acknowledge the contribution made by the World Rugby tournament managers for facilitating and supporting the implementation of this study. The authors would also like to acknowledge the valuable support provided by the medical teams working with the participating countries at each of the competitions and who provided injury, illness and training exposure data.

Funding The study was funded by World Rugby, Dublin, Ireland.

Competing interests None declared.

Ethics approval World Rugby Institutional Ethics Committee. 
Provenance and peer review Not commissioned; externally peer reviewed.

C Article author(s) (or their employer(s) unless otherwise stated in the text of the article) 2017. All rights reserved. No commercial use is permitted unless otherwise expressly granted.

\section{REFERENCES}

1 Rugby W. The history of rugby sevens. http://www.worldrugby.org/sevens/history-ofsevens (accessed 21 November 2016).

2 Rugby W. About the HSBC world rugby sevens series. http://www.worldrugby.org/ sevens-series (accessed 21 November 2016).

3 Jakoet I, Noakes TD. A high rate of injury during the 1995 rugby world cup. S Afr Med J 1998;88:45-7.

4 Best JP, McIntosh STN, Cup RW. Injury surveillance project. Br J Sports Med 2003:2005:812-7.

5 Fuller CW, Laborde F, Leather RJ, et al. International rugby board rugby world cup 2007 injury surveillance study. Br J Sports Med 2008:42:452-9.

6 Fuller CW, Sheerin K, Targett S, et al. Rugby World Cup 2011: International rugby board injury surveillance study. Br J Sports Med 2011;2013:1184-91.

7 Fuller CW, Taylor A, Kemp SPT, et al. Rugby World cup 2015: World rugby injury surveillance study. Br J Sports Med 2016:1-7.

8 Brooks JH, Fuller CW, Kemp SP, et al. Epidemiology of injuries in english professional rugby union: part 1 match injuries. Br J Sports Med 2005;39:757-66.

9 Rugby Football Union. England professional rugby injury surveillance project: 2014-15 season report, 2016. Rugby Football Union; Twickenham. http://www.englandrugby. com/mm/Document/General/General/01/31/72/86/InjurySurveillanceReport_201415_SINGLE_22Mar16_English.pdf (accessed 21 Nov 2016).

10 Waller AE, Feehan M, Marshall SW, et al. The New Zealand rugby injury and performance project: I. design and methodology of a prospective follow-up study. $\mathrm{Br} J$ Sports Med 1994:28:223-8.

11 Chalmers DJ, Simpson JC, Depree R, Injury TR. Tackling rugby injury: lessons learned from the implementation of a five-year sports injury prevention program. J Sci Med Sport 2004;7:74-84

12 Quarrie KL, Gianotti SM, Hopkins WG, et al. Effect of nationwide injury prevention programme on serious spinal injuries in New Zealand rugby union: ecological study. BMJ 2007;334:1150
13 Kemp SP, Hudson Z, Brooks JH, et al. The epidemiology of head injuries in english professional rugby union. Clin J Sport Med 2008;18:227-34.

14 Fuller CW, Taylor A, Raftery M. Epidemiology of concussion in men's elite Rugby-7s (Sevens World Series) and Rugby-15s (Rugby World Cup, Junior World Championship and Rugby Trophy, Pacific Nations Cup and English Premiership). Br J Sports Med 2015:49:478-83.

15 Fuller GW, Kemp SP, Decq P. The international rugby board (IRB) Pitch Side Concussion Assessment trial: a pilot test accuracy study. Br J Sports Med 2015;49:529-35.

16 Fuller CW, Fuller GW, Kemp SPT, et al. Evaluation of world rugby's concussion management process: results from Rugby World Cup 2015. Br J Sports Med 2016.

17 Fuller CW, Taylor AE, Raftery M. Does long-distance air travel associated with the sevens world series increase players' risk of injury? Br J Sports Med 2015:49:458-64.

18 Fuller CW, Taylor AE, Raftery M. Should player fatigue be the focus of injury prevention strategies for international rugby sevens tournaments? Br J Sports Med 2016;50:682-7.

19 Quarrie KL, Raftery M, Blackie J, et al. Managing player load in professional rugby union: a review of current knowledge and practices. Br J Sports Med 2016:bjsp orts-2016-096191.

20 Orchard J. Orchard sports injury classification system (OSICS). Sport Health 1995;11:39-41.

21 Fuller CW, Molloy MG, Bagate C, et al. Consensus statement on injury definitions and data collection procedures for studies of injuries in rugby union. $\mathrm{Br} / \mathrm{Sports}$ Med 2007:41:328-31.

22 Kirkwood BR, Sterne JAC, Statistics EM. Oxford: Blackwell science. 2003.

23 Junge $A$, Engebretsen L, Mountjoy ML, et al. Sports injuries during the summer olympic games 2008. Am J Sports Med 2009;37:2165-72.

24 Engebretsen L, Soligard T, Steffen K, et al. Sports injuries and illnesses during the London summer olympic games 2012. Br J Sports Med 2013;47:407-14.

25 Rugby W. World rugby research funding general principles and priorities. http:// playerwelfare.worldrugby.org/?documentid=148 (accessed 21 November 2016).

26 Brooks JH, Fuller CW, Kemp SP, et al. An assessment of training volume in professional rugby union and its impact on the incidence, severity, and nature of match and training injuries. J Sports Sci 2008;26:863-73.

27 Windt J, Gabbett TJ. How do training and competition workloads relate to injury? the workload -injury aetiology model. Br J Sports Med 2016:bjsports-2016-096040. 